\title{
EFL Undergraduate Students' Perspectives of the Methodology of Teaching Employed by their Teachers in the Teaching- Learning Context
}

\author{
Mohammed M. Obeidat \\ Faculty of Educational Sciences, The Hashemite University, P.O Box 330127, Zarqa 13133, \\ Jordan. \\ E-mail:moh.obai29@yahoo.com
}

\begin{abstract}
This current study aimed to explore English as a foreign language (EFL) students' opinions on the methodology of teaching used by their teachers. More specifically, the study aimed to investigate their perspectives of performance techniques the teachers used in the classroom. The sample consisted of 190 male and female students chosen randomly from the population of the study $(\mathrm{N}=650)$. The research instrument used in this study was a questionnaire including items derived from the literature related to teaching and learning and to students' attitudes toward method of teaching. Results indicated students' positive attitudes toward the methods of teaching used by their teachers. They also revealed that the teachers were very active with regard to preparation for lectures, presenting the aim clearly from the very beginning, listening to students' opinions and addressing their concerns, encouraging students to remember rules and sentence patterns to apply them in communication, creating a friendly and purposeful environment in the classrooms and displaying enthusiasm in the teachinglearning context. Moreover, results showed no significant differences between the attitudes of males and females. However, there were significant differences between their attitudes according to study level and grade point average. In light of these results, recommendations were suggested.
\end{abstract}

Keywords: EFL undergraduates, perspectives, teachers, methodology of teaching

DOI: $10.7176 / \mathrm{JEP} / 10-33-18$

Publication date: November $30^{\text {th }} 2019$

\section{Introduction}

\subsection{Higher Education and Method of Teaching}

Higher education plays an essential role in society by creating new knowledge, transmitting it to students and fostering innovation. Quality teaching in higher education matters for student learning outcomes (Henard, \& Roseveare, 2012). In order to achieve this aim, education should not only focus on the quality of content materials but also on good teaching methods. The reason lies in the fact that these methods normally affect students' competence in any field of study.

A study of extent literature on effectiveness of teaching in both scholastic and undergraduate levels reveals that defining effectiveness is inherently contentious (Allan, Clarke \& Jopling, 2009). However, teaching is regarded as one of the main components in educational planning, which is a key factor in conducting educational plans. Despite the importance of good teaching, the outcomes are far from ideal. Research considers the mixed method (studentcentered together with teacher-centered) as the best in the teaching-learning context. But, when the teachers teach using this method, they confront with some barriers and requirements; some of these requirements are prerequisite in instructors' behavior and outlook. Moreover, there are some major barriers associated with the instructors' performance 
while others are related to laws and regulations (Bidabadi, Isfahani, Rouhollahi, \& Khalili, 2016). Therefore, this current study is an attempt to shed light on college educations in general and method of teaching in particular. The study also tries to distinguish college from high school with respect to the way the students learn their subjects.

Though there are many approaches to teaching method in teaching English as a foreign language (TEFL)/teaching English to speakers of other languages (TESOL), two teaching methods are common in English as a foreign language (EFL) certification programs. These methods are present, practice and production (ppp) or engage, study and activate (ESA). With regard to "PPP", "presentation" involves presenting the target language to the students generally through eliciting and cuing of the students to see if they know it and then providing the language if no one does; "Practice" where the students practice the target language in one to three controlled activities; and "Production" where the students take the target language and use it in conversations. With respect to "ESA", it is slightly different in that it is designed to allow movement back and forth between the stages. It uses more elicitation and stresses the students' engagement in the early stage of the lesson. Both the elicitation of students' knowledge and ideas and their engagement are excellent ideas in any lesson regardless of the methodology of teaching (TEFL Educator, 2018: 1-2).

Many courses have been developed to give non-native students of English language the chance to be more competent. The American Language and Culture Institute (ALCI), for example, provides intensive English language instruction and introduces the American culture and the higher education system to international students. The students normally participate in various recreational and educational activities designed to facilitate a smooth transition to the university environment. This institute has been designed for students whose first language is not English. The EFL courses offered an integrated whole-language approach to the English language, through intensive reading, writing, speaking, and listening, focusing on communicative competence at their goals (Sarraj, 2001). However, the experience and observation as learners and teachers of English as a foreign language convince us that memorization seems to be a vital learning strategy, provided that memorization is used appropriately to help students internalize what they learned and to apply it in actual communication. As non-native speakers, we should remember rules, sentence structures and vocabulary systematically in order to apply these in communication (Oanh, 2006).

\subsection{Higher Education: Method Problem and Interest}

Research highlights a fundamental problem which shows that most high school graduates do not know how to learn or even what is meant to learn something. Actually, the graduates from high school feel that learning must come down to them from their instructors. That may be suitable for the goals of high school, but it is not acceptable at the university level (Zucker, 1996). The main strategy of modern education at this level should focus on the students' independent activity, the organization of self-environments and experimental and practical training, where students have a choice of actions and can use initiatives as well as training programs where students can work in a comfortable rhythm. The use of interactive methods of training encourages interest in the profession, promotes the efficient acquisition of training material, forms pattern of conduct, provides high motivation and contributes to the complex competences of future interests (Nadezhda, Yakovleva, Evgeny, \& Yakovlev, 2014).

Researchers discuss methods of teaching in higher education and highlight reasons for interest in them. They reflect on the loss of importance in this area and raise questions about how 
education tends to decrease production, ignoring its social functions. They locate three aspects of the importance of the methodology. First, the declining importance or the value and character that has been awarded the management of a set of techniques, tools and instruments taught easy application making it uninteresting to students. Second, the materials allotted to the methodology have been restricted to instrument techniques and management tools. Third, the teaching method is to be characterized as a practice based on manual and often taught by teachers with an insufficient profile (Gutierrez \& Villegas, 2015, pp. 378-382). Therefore, requests for change in teaching methodology at all educational levels are regarded to be expected consequences because of the rapid technological developments and today's dynamic and complex reality. To improve educational achievement and student vocational training at the university, it is required to use alternative methods and procedures of teaching (Mocinic).

A declining unit of teaching resource has put the spotlight on teaching methods because teaching staff costs are a high proportion of total costs within universities. Greater focus on and publicity about, performance indicators of teaching quality have also increased the attention paid to teaching methods. Developments in technologies for communicating and disseminating information have a large potential impact on the practice of teaching because teaching is an activity in which communicating and disseminating information are significant aspects (Bourner \& Flowers, 1997).

Despite the researchers' reflection on the loss of method of teaching at the undergraduate level, it remains vital to students in the teaching-learning context. Many methods, strategies and techniques have been suggested so that the teachers can be more effective while teaching. In Jordan, they are normally discussed with these instructors during a two-week course held immediately after their appointment at the university. The instructors are also informed with the necessity of using all the available resources in the department or at the faculty. In addition, they are encouraged to be serious with regard to preparation, classroom management, relationship with the students, and evaluation. Many studies were conducted on English as a foreign language (EFL) students' perspectives of a specific method or specific ones employed by their teachers in the classroom. A few of these studies attempted to explore EFL students' views about their teachers' methodology of teaching, in general. Therefore, the present study has come to the scene to explore university students' perspectives of this methodology.

\subsection{Study aims}

This current study mainly aims at investigating undergraduate EFL students' perspectives of the methodology of teaching used by their teachers. More specifically, the study aims at exploring their opinions on some techniques teachers use while teaching. All in all, the study attempts to answer the four research questions:

1. How do EFL students see their teachers" methodology of teaching in general?

2. What are the techniques EFL teachers' employ most/least as perceived by their students?

3. Are there any statistically significant differences $(\alpha=0.05)$ between the means of students' responses to their teachers' method of teaching according to study level?

4. Are there any statistically significant differences $(\alpha=0.05)$ between the means of students' responses to their teachers' method of teaching according to grade point average?

\section{Literature Review}

Teaching methods are regarded to be an important factor which normally influences learning outcomes in general and/or foreign language learning in particular. Various studies were conducted about methods of teaching. For example, Carpenter (2006) study identified 
effective teaching methods for large class environment. Using students learning outcomes as the criteria for effectiveness, several commonly-used teaching methods (lecture, lecture/discussion communication, Jigsaw, case study, team project) were applied and evaluated in a large class setting. Participants consisted of 109 students $(82 \%$ females and $18 \%$ males) were chosen randomly to achieve the aim of the study. A repeated measure ANOVA procedure was used to explore differences in the students' mean scores between the pre-tests and post-tests for each of the teaching methods examined in the study. Results revealed that student performance improved under the lecture method as compared to the lecture/discussion and team project method. In contrast, student improvement under the lecture method was not as positive as the Jigsaw method.

Moreover, Nazara (2011) investigated 40 students' perspectives of an English teaching study program in Jakarta. The program was allotted to developing their speaking skill. A questionnaire and semi-structured interviews were developed to elicit their responses to methods of teaching used by their teachers with respect to speaking. The findings revealed that all participants considered speaking important and were willing to deal with the necessities to master it. They insisted on spending longer times to practice the skill. The study concluded by suggesting the need to create a friendly and conducive environment in the classroom.

In terms of the teacher's use of written feedback on students' written essays, Mahfoodh and Panadian (2011) investigated EFL students' reactions to and perceptions of their teachers' written feedback. Data were collected using multiple methods that included semi-structured interviews, think aloud protocols, teachers' written feedback, and students' written essays. Results revealed that students perceived their teachers' written feedback as useful and very important for the development of their written skills. They also indicated teachers' wording of written feedback and handwriting had their impact on EFL students' affective reactions to and perceptions of their teachers' written feedback.

Ahmed, Yossatorn, and Yossiri (2012) investigated the student attitude toward activities in an EFL classroom in a Thai university. The participants of the study included $1^{\text {st }}$-year students who had studied speaking course during second the semester of the academic year. The data was collected through class observations and semi-structured interviews. The researchers found promising results with regard to students' attitude toward teacher using activities in EFL class. More than half of the participants think teacher's use of activities determined their success in language learning. However, less than half of them showed dissatisfaction with regard to related to the EFL teacher use of humor on their cultures as part of his/her teaching. Al Sharaeai (2012) investigated students' perspectives about the use of their first language in English classrooms. He analyzed their opinions on different issues related to first language use. The analysis was conducted on data from an online survey and follow-up interviews of 51 total participants. The results showed that $41 \%$ of the participants agreed that they preferred the English-only policy in their English classrooms, while 25\% strongly agreed that they preferred using this policy. However, only $4.5 \%$ strongly disagreed to adopt using the English-only policy. This shows that students preferred to speak English only in an English class.

Concerning L2 use in the classroom, Hajizadeh and Salahshour (2013) identified the main features which characterize an effective EFL instructor according to students majoring in English. In order to do so, a 58-item questionnaire was administered to 42 students who were 
studying English ranging from pre-intermediate to advanced levels at a prominent language school in Tabriz, Iran. Regarding the method of teaching used in the classroom, the students showed a preference towards teachers who encourage students to use the L2 in the classroom. In addition, using the students' native language in the classroom was not considered as a merit by the majority of students. Finally, students favored teachers who provide detailed explanation before and during the reading and listening tasks.

Kang and Ting (2013) explored students' perspective of effective teaching and learning in the British higher education system in general. To investigate the differences in level of knowledge of UK teaching methods between three subgroups of students and their attitudes towards those methods, to examine whether or not there was a relationship between students' knowledge about these methods and their attitudes towards them, twenty participants at one university in UK were chosen. A survey research method was applied. Data collection was conducted through questionnaire with closed items. Results revealed a significant difference between Western and Eastern students in their knowledge of teaching methods used in UK universities. Results also showed neither a positive nor a negative relationship between student knowledge of teaching methods and their attitudes towards them.

Kwon (2014) conducted a classroom action research in writing and presentation skills at a mid-sized university in Thailand. The students completed one writing assignment and gave a related presentation for each project. Then the researcher examined the students' perspectives on the collaborative writing tasks they were engaged in. Pre- and post-questionnaires, student reflective Journal entries, and post interviews were used. Findings showed that although most students perceived group work positively, they faced some challenges, including differing levels with groups, difficulty in decision making processes, and relationships with their peers. The study suggested teachers need to listen to the student's voice and address their concerns when implementing and adapting collaborative writing and peer response.

Mermelstein (2015) explored whether three teaching approaches (instructor-centered, studentcentered, and content-centered) meet the educational needs of students. The data was collected from 225 Taiwanese EFL university students with respect to these three approaches. Findings indicated that the participants clearly recognized the differences among the teaching approaches, had a clear preference toward the student-centered approach, and held more positive attitudes toward student-centered learning.

Toraby and Modarresi (2018) examined the association between teachers' emotions and students' perspectives towards their teachers' success in teaching, and to determine the predictors of students' views on teachers' pedagogical success. In doing so, 80 homogeneous university students majoring in TEFL from different universities in the northeast of Iran and 20 EFL teachers participated in the study. Results showed a moderate, positive correlation between teachers' emotions and students' views on teachers' pedagogical success. They also showed that displaying emotions such as pride and enjoyment could be used to motivate the students.

It is apparent to the reader that the majority of studies reviewed were conducted on EFL students' perspectives of a specific method or specific ones used by their teachers' in the classroom. That is, the studies were conducted on students' views about lecture, lecture/discussion, Jigsaw, the use of speaking, the teachers' use of written feedback, the use of first language, collaborative writing tasks, and teachers' emotions and their success. It is 
also clearly seen that only a few studies were conducted on EFL students' perspectives of their teachers' methodology of teaching, in general. This encouraged the researcher to conduct the present study to fill the gap in the literature related to university EFL students' attitudes toward this methodology.

\section{Methodology}

A quasi-experimental study was employed to explore EFL students' perspectives of their teachers' methodology of teaching in the teaching-learning context. Due to the problem encountered by the students at the university level regarding teachers' emphasis on the lecturing method, this current study is seen as an attempt to shed light on this pedagogic aspect and to remind administrators, policy-makers, and the teachers themselves of the necessity of varying their methods of teaching.

\subsection{Instrument}

This current study employed a questionnaire, through which the EFL students' perspectives of the method of teaching used by their teachers were explored. Two major variables were also examined: study year, and grade point average (2-2.49 points/ satisfactory, 2.50-2.99/ good, $3=3.49 /$ very good, $3.50-4 /$ excellent). It is noteworthy in this regard that the interview was not used as the students have not a sufficient idea about the methods of teaching. Therefore, the questionnaire was employed for its items to remind students to judge their instructors' performance appropriately. In order to find out the reliability factor of the questionnaire, the test-retest way of analysis was administered to a pilot sample of 40 students who were not involved in the study. The results of the analysis indicated that the correlation coefficient was found to be 0.84 , which is statistically acceptable. The final draft of the questionnaire included 24 items. These items had four alternatives (Strongly agree, Agree, Disagree, and Strongly disagree) in order for the students to read them carefully and put a tick next to each and under the alternative, which represents their attitudes toward it. Then, the questionnaire was subjected to a reliability assessment using an SPSSX statistical package. It demonstrated an internal reliability, achieving a Cronbach alpha of $(\alpha=.77)$ with all the items producing significant item-total scale correlation.

\subsection{The Setting and participants of the Study}

The research was conducted in the English Language Department at the Hashemite University. The participant of the study were 190 university EFL students who were in their second-, third-, and fourth-years of study. Only $26 \%$ of the sample are males, whereas $74 \%$ are females. However the table below shows the distribution of students over the variables of the study, study-year and grade point average.

Table 1. The distribution of the participants over study level and grade point average

\begin{tabular}{|l|c|c|}
\hline Variables & Frequency & Percent \\
\hline Study-year & 79 & \\
$2^{\text {nd }}$-year student & 73 & 42 \\
$3^{\text {rd }}$-year student & 38 & 38 \\
$4^{\text {th }}$-year student & & 20 \\
\hline Grade point average & 68 & 36 \\
$2-2.49$ & 57 & 30 \\
$2.50-2.99$ & 32 & 17 \\
$3-3.49$ & 33 & 17 \\
$3.5-4$ & 190 & 100.0 \\
\hline Total & & \\
\hline
\end{tabular}




\subsection{Limitations}

This study was limited to 190 students studying in the English Language Department at the Hashemite University. They were second- $(\mathrm{N}=79)$, third- $(\mathrm{N}=73)$, and fourth- $(\mathrm{N}=38)$ year students chosen randomly from the population of the study.

\subsection{Data Analysis}

Particular statistical techniques in the data analysis were used. They were the means, standard deviations, and the One-way ANOVA. The means and standard deviations were used for the arrangement of the items of the questionnaire. That is, they were employed for ranking the means and standard deviations of students' responses to the questionnaire items. They were also used with the One-way ANOVA and F-value. And finally, they were used with the Scheffe Test to show whether there were any significant differences between each pair of study year and whether there was variance in the means and standard deviations of students' responses according to grade point average.

\section{Results}

4.1 Results Related to the first Research Question

In order to answer the first question How do EFL students perceive their instructors' method of teaching in general?, the means and standard deviations of students' responses were computed. The ranges, which revealed whether the students' attitude was positive or negative, were also computed and determined in advance (i.e., 1.00-2.5 negative and 2.51-4.00 positive). As shown in Table 2.

Table 2. Mean (M) and Standard Deviation (SD) of students' responses on the instructors' method of teaching

\begin{tabular}{|c|c|}
\hline Mean & Std. Deviation \\
\hline 2.80 & .290 \\
\hline
\end{tabular}

The table above shows that the total mean of students' responses to the question is 2.80 . This means that students' attitude toward their instructors' method of teaching is positive in general.

\subsection{Results Related to the Second Research Question}

To answer the second question What are the techniques EFL instructors employ most/least as perceived by their students?, the means and standard deviations of techniques the instructor uses were computed and ranked in a descending order. As presented in Table 3:

Table 3. Mean (M) and Standard Deviation (SD) of the performance techniques used by EFL instructors as perceived by their students

\begin{tabular}{|l|c|c|}
\hline \multicolumn{1}{|c|}{ Item } & M & SD \\
\hline $\begin{array}{l}\text { My instructors are usually prepared for } \\
\text { their lectures. }\end{array}$ & 3.13 & .559 \\
\hline $\begin{array}{l}\text { My instructors normally present the aim } \\
\text { of the activity and then give students the } \\
\text { chance to practice it. }\end{array}$ & 3.13 & .670 \\
\hline $\begin{array}{l}\text { My instructors normally listen to } \\
\text { students voice and address their } \\
\text { concerns. }\end{array}$ & 3.05 & .685 \\
\hline $\begin{array}{l}\text { My instructors encourage students to } \\
\text { remember rules and sentence patterns } \\
\text { systematically to apply these in } \\
\text { communication. }\end{array}$ & & \\
\hline
\end{tabular}




\begin{tabular}{|c|c|c|}
\hline $\begin{array}{l}\text { My instructors create a friendly and } \\
\text { purposeful environment in the } \\
\text { classrooms. }\end{array}$ & 3.00 & .756 \\
\hline $\begin{array}{l}\text { My instructors often display enthusiasm } \\
\text { to motivate students learning. }\end{array}$ & 2.97 & .658 \\
\hline $\begin{array}{l}\text { My instructors focus on communicative } \\
\text { competence through intensive reading, } \\
\text { writing, speaking and listening activities }\end{array}$ & 2.94 & .672 \\
\hline $\begin{array}{l}\text { My instructors encourage independent } \\
\text { activity so that students can work in a } \\
\text { comfortable environment. }\end{array}$ & 2.92 & .769 \\
\hline $\begin{array}{l}\text { My instructors use verbal communication } \\
\text { as a means and a goal at the same time. }\end{array}$ & 2.92 & .645 \\
\hline $\begin{array}{l}\text { My instructors employ teaching methods } \\
\text { which show that they are well-trained. }\end{array}$ & 2.88 & .656 \\
\hline $\begin{array}{l}\text { My instructors insist that students should } \\
\text { have longer times to practice speaking. }\end{array}$ & 2.87 & .789 \\
\hline $\begin{array}{l}\text { My instructors stress the engagement of } \\
\text { students throughout the stages of the } \\
\text { lesson. }\end{array}$ & 2.81 & .734 \\
\hline $\begin{array}{l}\text { My instructors often use Arabic while } \\
\text { presenting and explaining literal and } \\
\text { linguistic points. }\end{array}$ & 2.81 & .732 \\
\hline $\begin{array}{l}\text { My instructors use the English-only } \\
\text { policy in their classrooms. }\end{array}$ & 2.80 & .682 \\
\hline $\begin{array}{l}\text { My instructors give students the chance to } \\
\text { participate in classroom activities. }\end{array}$ & 2.77 & .759 \\
\hline $\begin{array}{l}\text { My instructors vary their teaching } \\
\text { methods, using lectures, discussion, and } \\
\text { team work. }\end{array}$ & 2.74 & .899 \\
\hline $\begin{array}{l}\text { My instructors insist on giving traditional } \\
\text { exams and ignore project work and } \\
\text { assignments. }\end{array}$ & 2.66 & .771 \\
\hline $\begin{array}{l}\text { My instructors provide students with } \\
\text { written feedback on their writing. }\end{array}$ & 2.63 & .806 \\
\hline $\begin{array}{l}\text { My instructors do not allow students to } \\
\text { participate in educational and recreational } \\
\text { activities. }\end{array}$ & 2.62 & .701 \\
\hline $\begin{array}{l}\text { My instructors use group work when } \\
\text { implementing collaborative writing tasks. }\end{array}$ & 2.56 & .808 \\
\hline $\begin{array}{l}\text { My instructors take only } 25 \% \text { of class } \\
\text { time and usually allow students to interact } \\
\text { and brain storm one another. }\end{array}$ & 2.53 & .808 \\
\hline $\begin{array}{l}\text { My instructors allow students to use } \\
\text { Arabic during class times. }\end{array}$ & 2.47 & .788 \\
\hline $\begin{array}{l}\text { My instructors do not use the whole } \\
\text { language approach and focus only on } \\
\text { students' grammatical mistakes. }\end{array}$ & 2.47 & .788 \\
\hline $\begin{array}{l}\text { My instructors insist on the teacher- } \\
\text { centered approach and do not allow } \\
\text { students to participate. }\end{array}$ & 2.45 & .833 \\
\hline
\end{tabular}

Table (3) shows that the sample students perceived their teachers very active with regard to preparation for their lectures, presenting the aim and then giving students the chance to practice it, listening to students' opinions and addressing their concerns, encouraging students to remember rules and sentence patterns to apply them in communication, creating a friendly and purposeful environment in the classrooms and displaying enthusiasm in the teaching- 
learning context. As also shown in the table above, the performance techniques which were the least employed by the teachers are associated with using the first language, the whole language approach, and with teacher-centeredness.

\subsection{Results Related to the Third Research Question}

Concerning the third question which explores whether there were statistically significant differences $(=0.05)$ between the means of students' responses to the teachers' method of teaching according to study level, the mean square, the F- and sig-values were used. As table 4 presents these findings:

Table 4.The Mean square, the F-value and the Sig.-value of students' responses due to study level

\begin{tabular}{|c|c|c|c|c|c|}
\hline & $\begin{array}{c}\text { Sum of } \\
\text { Squares }\end{array}$ & df & Mean Square & F & Sig. \\
\hline $\begin{array}{c}\text { Between } \\
\text { groups }\end{array}$ & 1.336 & 2 & .668 & 8.557 & .000 \\
Within Groups & 14.597 & 187 & .078 & & \\
\hline
\end{tabular}

Table (4) shows that there are statistically significant differences $(\alpha=0.05)$ according to study level. Means and standard deviations of students' responses were calculated as stated in Table 5:

Table 5. Means (M), Standard Deviations (SD) of descriptive statistics related to students' responses according to study level

\begin{tabular}{|c|c|c|c|}
\hline Study level & N & M & SD \\
\hline $\mathbf{2}^{\text {nd }}$ Year student & 79 & 2,72 & .292 \\
$\mathbf{3}^{\text {rd }}$ year student & 72 & 2.80 & .265 \\
$\mathbf{4}^{\text {th }}$ Year student & 39 & 2,95 & .279 \\
\hline Total & 190 & 2.80 & .290 \\
\hline
\end{tabular}

Table (5) shows a slight variance in the means of students' responses according to study level. In order to find out whether there were statistically significant differences $(=0.05$ between each pair of study-year, the Pairwise Multiple comparisons Post Hoc Scheffe Test was used. As shown in Table 6:

Table 6. Pairwise Multiple Comparisons Post Hoc Scheffe Test and each pair of study level

\begin{tabular}{|c|c|c|c|c|}
\hline (I) Group & $\mathbf{( J )}$ group & Mean difference & Std. Error & Sig. \\
\hline $\begin{array}{l}\mathbf{2}^{\text {nd }} \text { Year } \\
\text { students }\end{array}$ & $\mathbf{3}^{\text {rd }}$ year students & -.078 & .046 & .089 \\
\hline $\begin{array}{c}\mathbf{4}^{\text {th }} \text { Year students } \\
\text { students }\end{array}$ & $\mathbf{2}^{\text {nd }}$ Year students & -.226 & .055 & .000 \\
\hline $\begin{array}{l}\mathbf{4}^{\text {th }} \text { Year } \\
\text { students }\end{array}$ & $\mathbf{2}^{\text {nd }}$ Year students & .078 & .046 & .008 \\
& $\mathbf{3}^{\text {rd }}$ Year students & -.148 & .056 & .000 \\
\end{tabular}

Table (6) shows no statistical significant differences $(\boldsymbol{\alpha}=0.05)$ between the means of thirdand fourth- year students' responses in favor of the fourth-year ones. The table also shows no statistical significant differences $(\boldsymbol{\alpha}=0.05)$ between the means of second- and fourth-year students' responses in favor of the later. In addition, the table shows no statistical significant 
differences $(\boldsymbol{\alpha}=0.05)$ between the means of second- and third-year students' responses.

4.4 Results Related to the fourth Research Question

Regarding the fourth question which examines whether there were statistically significant differences $(\boldsymbol{\alpha}=0.05)$ between the means of students' responses to their teachers' method of teaching according to grade point average, the analysis of variance (One-Way ANOVA) in Table 7 was used.

Table 7. Results of ANOVA related to students' responses due to study level

\begin{tabular}{|l|c|c|c|c|c|}
\hline & $\begin{array}{c}\text { Sum of } \\
\text { Squares }\end{array}$ & df & Mean Square & F & Sig. \\
\hline Between & .980 & 3 & .327 & 4.062 & .008 \\
groups & 14.953 & 186 & .080 & & \\
Within & & & & & \\
Groups & & & & & \\
\hline
\end{tabular}

Table (7) shows statistical significant differences $(\boldsymbol{\alpha}=0.05)$ between students' responses to their teachers' method of teaching according to grade point average. Means and standard deviations of students' responses according to grade point average were calculated. As shown in Table 8:

Table 8. Means (M), Standard Deviations (SD) of descriptive statistics related to students' responses according to grade point average

\begin{tabular}{|c|c|c|c|}
\hline $\begin{array}{c}\text { Grade point average } \\
\text { groups }\end{array}$ & N & M & SD \\
\hline $\mathbf{2 - 2 . 2 . 4 9}$ & 68 & 2.73 & .298 \\
$\mathbf{2 . 5 0 - 2 . 9 9}$ & 57 & 2.78 & .274 \\
$\mathbf{3 - 3 . 4 9}$ & 32 & 2.85 & .291 \\
$\mathbf{3 . 5 0 - 4}$ & 33 & 2.93 & .261 \\
\hline Total & 190 & 2.80 & .290 \\
\hline
\end{tabular}

Table (8) shows somewhat variance in the means and standard deviations of students' responses according to grade point average. Pairwise Multiple Comparisons Post Hoc Scheffe Test was conducted as in Table 9.

Table 9. Results of Scheffe Test related to grade point averages

\begin{tabular}{|c|c|c|c|c|}
\hline $\begin{array}{c}\text { Grade point } \\
\text { average }\end{array}$ & Grade point averages & Mean difference & Std. Error & Sig. \\
\hline $\mathbf{2 . 0 0 - 2 . 4 9}$ & $\mathbf{2 . 5 0 - 2 . 9 9}$ & -.053 & .051 & .299 \\
& $\mathbf{3 - 3 . 4 9}$ & -.117 & .061 & .055 \\
& $\mathbf{3 . 5 0 - 4 . 0 0}$ & -.200 & .060 & .001 \\
\hline $\mathbf{2 . 5 0 - 2 . 9 9}$ & & .053 & .051 & .299 \\
& $\mathbf{2 - 2 . 4 9}$ & -.064 & .063 & .307 \\
& $\mathbf{3 - 3 . 4 9}$ & -.147 & .070 & .019 \\
\hline $\mathbf{3 . 5 0 - 4}$ & .117 & .061 & .055 \\
& & .064 & .063 & .307 \\
& $\mathbf{2 - 2 . 4 9}$ & -.083 & .070 & .240 \\
\hline $\mathbf{3 . 5 0 - 4}$ & $\mathbf{2 . 5 0 - 2 . 9 9}$ & .300 & .060 & .001 \\
& $\mathbf{3 . 5 0 - 4}$ & .147 & .062 & .019 \\
& $\mathbf{3 - 2 . 4 9}$ & 083 & .070 & .240 \\
\hline
\end{tabular}

Table (9) shows statistical significant differences ( $\boldsymbol{\alpha}=0.05$ ) between groups 2.00-2.49 and $3.50-4.00$ in favor of 3.50-4.00. The table also shows statistical significant differences $(\boldsymbol{\alpha}=$ 
0.05 ) between groups 2.50-2.99 and 3.50-4.00 in favor of the later. In addition, the table shows no statistical significant differences $(\boldsymbol{\alpha}=0.05)$ between group 3-3.49 and the other groups and between 3.50-4 and the other ones.

\section{Discussion}

The results of the study revealed that the students' perspectives of their teachers' methodology of teaching were positive in general. They also showed that the students perceived their teachers very active with regard to preparation for their lectures, presenting the aim and then giving students the chance to practice it, listening to students' voice and addressing their concerns, encouraging students to remember rules and sentence patterns to apply them in communication, creating a friendly and purposeful environment, and displaying enthusiasm in the teaching-learning context. Students' positive attitudes toward their instructors' methodology of teaching indicate their satisfaction with the pedagogical or methodological procedures employed regardless of whether these procedures are traditional or contemporary. Regarding the opinions on some performance techniques, the students indicated that their teachers prepared for their lectures well. This highlights the importance of educational planning in the process of teaching (Bidabadi, et al., 2016). Their subjects indicated that the instructors normally presented the aim of the activity and then gave students the chance to practice it. The method "ppp" is common in teaching English as a foreign language (TEFL Educator, 2018). Listening to students' opinions and addressing their concerns, creating a friendly and purposeful environment and displaying enthusiasm in the teaching-learning context have been suggested successively by (Kwon, 2014 \& Nazara, 2011). This also coheres with what (Torabi \& Modarressi, 2018) found that the instructor's display of emotions, such as enjoyment, could be used extensively to motivate the students. In addition, the result agrees with what Kwon (2014) recommended that teachers need to listen to the students' voice and address their concerns. In terms of students' encouragement to remember rules and sentence patterns, its importance has been highlighted by (Oanh, 2006) that memorization is used appropriately to help students internalize what they learned and to apply it in actual communication.

As also shown in the presentation of results, the performance techniques which were the least employed had been associated with not allowing students to use the first language, not using the whole language approach and with not insisting too much on the teacher-centered approach. This means that the teachers focused more on the English-only policy which was preferred by the majority of participants $(66 \%)$ in the study done by (Al Sharaeai, 2012). This also means that the teachers employed a traditional approach rather than a whole language one as recommended by many educators and methodologist. Sarraj (2001), for example, admired the whole language approach adopted by The American Language and Culture Institute (ALCI). Moreover, not insisting much on the teacher-centered approach may indicate that the instructors inclined more to the student-centered approach. This may cohere with what the students in the studies conducted by (Kwon, 2014 \& Mermelstein, 2015). That is, they held more positive attitudes toward student-centered learning. However, the results obtained by (Carpenter, 2006) revealed that student performance improved under the lecture method as compared to the lecture/discussion and team project method.

The results also showed significant differences according to study level. More specifically, they revealed significant differences between the means of second- and fourth-year students' responses in favor of the fourth-year ones. They also showed significant differences between the means of third- and fourth-year students' responses in favor of the fourth-year ones. It is 
not a strange phenomenon to see the significant differences in favor of the fourth-year students since they are more mature educationally, academically and emotionally. In other words, this maturity might have helped them to weigh up their instructors' methodology of teaching in a balanced way.

Moreover, the results indicated significant differences between students' responses to their instructors' method of teaching according to grade point average. This difference was apparent between 2.00-2.49 and 3.50-4.00 points in favor of 3.50-4.00. The table also revealed significant differences between groups 2.50-2.99 and 3.50-4.00 in favor of the later. It is a matter of fact to notice significant differences between the attitudes of low or middle and high achievers. It is also something natural to notice the significant differences in favor of high achievers (3.50-4 points). Once again, these achievers might be more mature and more serious in evaluating their instructors' performance and the teaching-learning context as a whole. However, these results counter what was found by kang \& Ting (2013) that neither a positive nor a negative relationship between student knowledge and level of achievement and their attitudes towards methods of teaching.

\section{Recommendations}

1. Policy-makers at the university level should develop teacher education programs for the instructors to be acquainted with the contemporary methods of teaching used in higher education institutions in developed countries.

2. Researchers on EFL in higher education ought to conduct similar studies in order for each study to complement the other. The purpose is to fill a gap in the literature associated with methods of teaching at the university level.

\section{Conclusion}

The findings of the current study were limited to the setting and participants in the study. However, it provides some important implications for EFL instructors. It also encourages researchers in teaching English as a foreign language (TEFL) not to focus on methods of teaching at the school level but to conduct studies in higher education to fill a gap in the literature related to the instructor's teaching methods in the view of his or her students.

It seems that university students' perspectives of their teachers' performance is of paramount importance in higher education. Therefore, these perspectives should be taken into account in order for universities to activate this aspect and develop instructor education programs in this regard. The emphasis ought not to be on the newly appointed instructors but also on the inservice ones for them to go along with the recent development in the field of methodology of teaching in general.

\section{Acknowledgement}

I would like to give my sincere and deep gratitude to the head of the English Language Department at the Hashemite University, D. Rabab'h. I would also like to thank Dr. Shboul, and Omari for their cooperation in the classroom. And finally, I am appreciative to Prof. Ali Farhan for proofreading this current research study.

\section{References}

Abu- Snoubar, T. (2017). An Evaluation of EFL Students' Attitudes toward English Language Learning in terms of Several Variables. International Journal of English Language Teaching, 5 (6), 18-34. Available online: www.eajournals.org

Ahmed, C., Yossatorn, Y., \& Yossiri, V. (2012). Students' Attitudes toward Teachers' Using 
Activities in EFL Class. International Journal of Academic Research in Business and Social Sciences, 2 (5), 158-164. Available online: www.hrmars.com/journals

Allan, J., Clarke, K., \& Jopling, M. (2009). Effective Teaching in Higher Education: Perceptions of First Year Undergraduate Students. International Journal of Teaching and Learning in Higher Education, 21(3), 362-372. Available online: www.isetl.org/ijtlhe/

Al Sharaeai, W. (2012). Students' Perspectives on the Use of L1 in English Classrooms. Theses and Dissertations, IOWA State University, 1-95. Available online: http://lib.dr.lastate.edu/etd

Bidabadi, N., Isfahani, A., Rouhollahi, A., \& Khalili, R. (2016). Effective Teaching Methods in Higher Education: Requirements and Barriers. Journal of Advances in Medical Education and Professionalism, 4 (4), 170-178. Available online: www.ncbi.nim.gov/pmc/articles

Bourner, T., \& Flowers, S. (1997). Teaching and Learning Methods in Higher Education: A Glimpse of the Future. Journal of Higher the Education Foundation, 9, 77-102. Available online: http://www.bbk.ac.uk/asd/boume.htm

Carpenter, J. (2006). Effective Teaching Methods for Large Scales. Journal of Family and Consumer Sciences Education, 24 (2), 13-23. Natefacs.org/pages.v24no02/v24no2

Gutierrez, D., \& Villegas, E. (2015). The Importance of Teaching Methodology in Higher Education: a Critical Look. Procedia-Social and Behavioral Sciences, 174, 377-382. Available online: http://doi.org/lj.sbs

Hajizadeh, N., \& Salahshour, N. (2013). Characteristics of Effective EFL Instructors. Procedia-Social and Behavioral Sciences, 70, 163-173. Available online: http://doi.org/10.1016/j.sbspro.

Henard, F., \& Roseveare, D. (1012). Fostering Quality Teaching-Higher Education Policies and Practices. OECD, IMHEP Programme on Institutional Management in Higher Education. Available online: http://Www. Occd: org/edn/imhe/QT \%20 policies \%20 and $\% 20$ practices.

Kang, Z., \& Ting, K. (2013). Student Attitudes Teaching Methods Used in Universities the UK. Review of European Studies, 5(4), 71-81. DOI:10.5539/res.v5n4.

Kwon, C. (2014). Student Perspectives on Group Work and Use of L1: Academic Writing in a University EFL Course in Thailand. Second Language Studies, 33 (1), 85-124. Available online: www.hawall.edu/sls/wp-content/uploads

Mahfoodh, O., \& Panadian, A. (2011). A Qualitative Case Study of EFL Students' Affective Reactions to and Perceptions of their Teachers' Feedback. English Language Teaching, 4 (3), 14-25. Doi:10.5539/elt.v4n3

Mermelstein, A. (2015). Asian EFL University Students' Preference toward Teaching Approaches. The CATESOL, 27 (2), 259-279. Files.eric.gov

Mocinic, S. (2012). Active Teaching Strategies in Higher Education. Metodicki Obsori, 15(7), 97-105. Pdfs.semanticscholar.org/ba81

Nadezhda, O., Yakovleva, A. Evgeny, V., \& Yakovlev, B. (2014). Interactive Teaching Methods in Contemporary Higher Education. Pacific Review, 16 (2), 75-80. Available online: http://doi.org//10.1016/j.pser.

Nazara, S. (2011). Students' Perceptions on EFL Speaking Development. Journal of English Teaching, 1(1), 28-43. Doi: 10.3354//jet.v1i1.50

Oanh, D. (2006). Memorization and EFL Students' Strategies at university Level in Vietnam. TESL-E, 10 (2), 1-21. Available online: www.test-ej.org/wordpress/issues/volume 10

Sarraj, S. (2001). English as a Foreign/Second Language-EFL and ESL. The Center for Regional and Continuing Education: University Catalog, 1999-2001, 1-2. 
En.wikipedia.org/wiki/English-as-a second or...

TEFL Educator (2018). EFL Teaching Methodology: Methods for Teaching English in the Classroom. 610E. Bell Road I 348, Phonenix AZ 85022. Available online: www.teachingenglish.org.uk

Toraby, E., \& Modarresi, G. (2018). EFL Teachers' Emotions and Learners' Views of Teachers' Pedagogical Success. International Journal of Instruction, 11 (20), 513-526. Available online: http://doi.org//12973/iji

Zucker, S. (1996). Teaching at the University Level. Notices of the AMS, 43(8), 363-365. Available online: www.ams.org/notices/199608/comm 